\title{
THE BASIC ELEMENTS OF THE TESTAMENT IN THE ENGLISH LEGISLATION
}

\section{L.D. Rath BOȘCA, B. BODEA}

\section{Laura-Dumitrana Rath Boșca}

Faculty of Juridical and Administrative Sciences

Agora University of Oradea, România

Doctoral School-Law Field, “UVT” University, Timișoara, Romania

*Correspondence: Laura-Dumitrana Rath Boșca, Agora University of Oradea, Piața

Tineretului no. 8, Oradea, Romania

E-mail: dumitra1970@yahoo.com

\section{Bogdan Bodea}

Faculty of Law, University of Oradea, România

*Correspondence: Bogdan Bodea, Faculty of Law, University of Oradea, România, str.

General Magheru, no. 26, Oradea, România

E-mail: avocatbodea@yahoo.com

\begin{abstract}
Common Law represents the second biggest contemporary judicial system. Immanent to a historical process which led to the creation of a community, common law represents a form of social solidarity. It is not the result of any social consent to obey a law as much as it is the participation of the society, through its exceptions, to the process of elaborating the law by which it functions. So, society itself is through a sort of syncretism the common law.

One the elementary concepts of common law is the doctrine of precedent which functions in parallel with organic laws in order to enhance both the results of judicial cases and the efficiency of the cases. In the English law, the testament is a representation of the wishes of a defunct person and the declaration of that persons wishes in relation to the belongings he wished to pass on after his death.
\end{abstract}

KEYWORDS: common law, precedent doctrine, will, judicial system, testacy, legatees.

\section{INTRODUCTION.}

Publius Iuventius Celsus, one of the most influential jurists of his time, said: "Law is technical but also art, the art of good and equity” (jus est ars boni et aequi) ${ }^{1}$.

Law is nothing more than a set of rules established and guaranteed by the state that aim to organize and "discipline" human behavior in the relations of society, in an environment that offers the protection of fundamental rights and freedoms.

These rules need to be known and accessible to everyone.

Mircea Djuvara stated that the historical past of a society „with all its institutions and its entire mentality” stands „at the basis of the whole right”.

„The legal consciousness of the society, which ultimately explains the whole of its right, in all its branches and manifestations, cannot be known in such a way as to claim scientific rigor”.

\footnotetext{
${ }^{1}$ Publius Iuventius Celsius, Digesta 111, Digesta (legal works)
} 
He considered that „sociology is, as a foundation, the basis of law, for without it we cannot understand it”" .

\section{BRIEF DESCRIPTION OF THE ENGLISH LAW - COMMON LAW -}

Between the structure of the English law - common law - and that of continental law, there are considerable differences.

Common law is the second largest legal system.

„For centuries, the development of legal systems has taken place in parallel, on the European continent, on one hand, and in the British Isles, on the other hand, without too frequent mutual contacts, and especially without any of these systems exerting a real influence on other. Thus two different legal environments were created, two closed legal worlds - the continental and the island - which ignored each other” ${ }^{3}$.

Law professor Rene David, an important and representative specialist of comparative law in the second half of the 20th century, showed how gravely influenced the ignorance of English law upon the economic life of France.

„The price with which French traders paid the indifference, lack of interest to their lawyers cannot be measured. It can be said that this price was high: it was only bearable because its burden was ultimately borne by the mass of consumers”.

Given that England has dominated the world trade for more than a century, it was inevitable that it would impose both the types of contracts in the practice of commercial relations and the jurisdiction of the English arbitration courts, even if the parties had other nationalities.

The technical elements of the common-law system have laid the foundations for international economic cooperation, and English and American contractual techniques are the basis for the whole international trade law.

„Common law appears as a form of legal experience that is related to the practice of law. ... Common-law announces a particular form of dealing with social issues perceived in their legalization, a tacit treatment (in the etymological sense of "ordination"), that is, an own government" 4 .

” When, by contrast, the tradition of common law claims to have knowledge of society, what does it refer to?

By contrast, the tradition of the common law system claims certain knowledge about society, but what are they? Basically, there are two elements that constitute the knowledge society, both equally important. The first element is the mastery with which a judge expresses a rule, this practice both in theory and practice demonstrates that adjudication is the best method of solving private problems. The second element is the knowledge of the judicial past in the form of the precedent; this form contains the wisdom of the best methods of government.

The government does not need a plan or should not operate based on a rigid plan, but the precedent is a good indicator of how new particular situations can be resolved based on

\footnotetext{
${ }^{2}$ M. Djuvara, Teoria generală a dreptului. Enciclopedia Juridică: Drept Raţional. Izvoare şi Drept Pozitiv, Bucharest: ALL, 1995, p. 300.

${ }^{3}$ Zlătescu V.D., Drept privat comparat, Bucharest, Oscar Print Publishing House, 1997, p. 245;

${ }^{4}$ Pierre Legrand, Dreptul comparat, Bucharest, Lumina Lex Publishing House, 2001, p. 43;
} 
particular situations in the past. Experience has legitimized this judicial practice both in a normative and an intellectual, philosophical way, within the framework of jurisprudence” 5 .

\section{DOCTRINE OF THE PRECEDENT IN THE COMMON LAW SYSTEM (COMMON LAW SYSTEM)}

The doctrine of the preceding is a professional use that began in the nineteenth century and became one of the most important sources of law in the English legal system. It dictates the use of some of the legal reports that are drafted by various sources (private or public) as common law in similar cases.

In principle, this procedure seems very simple, but it is a big problem in the democratic legislative system where all the laws are voted by the Parliament.

The fact that some people can impose laws without them being elected by the population may sound worrying, but surprisingly, this practice has helped develop a system that is currently effective and relatively quick.

This system operates on the basis of strict rules and on the basis of the power balance between the legislative and judicial branches. A first rule is the hierarchical one, only the Supreme Court of Great Britain, the Court of Appeal of England and Wales and the House of Lords have cases whose reports are common law.

This first rule hampers the number of cases that have a legislative role.

A second rule is that of different opinions that requires a judgment to have a unanimous verdict not a majority one. Either of these 3 courts have an odd number of judges ranging from 3 to 11 to avoid the possibility of a verdict with 2 equal parts in number and opposite.

By this rule, the system regains the cases again, but more importantly, ensures the certainty of cases with a legislative role.

One element is the balance between the legislative and the judiciary.

The parliament may declare an irrelevant judgment, even if the court decision remains valid, and this will not have a legislative role.

Another element that helped to modernize the legal system is the Constitutional Reform Act 2005, which brought a major change to the legislative system by introducing a Supreme Court.

Until 2005, the House of Lords, which is one of the two Chambers of Parliament, played the role of the Supreme Court, this function was traditionally owned by the House of Lords, but with the evolution of society the question of the separation of powers emerged, Parliament had both a legislative function as well as a judicial function, which is unacceptable in a democratic society because of the violation of the principle of the separation of powers in the state.

For this reason, it can be seen that most of the cases having a legislative function have reached the House of Lords. These rules provide for the limitation of cases that have an impact on the future of British jurisprudence.

The main elements of a common law are: ratio decidendi and obiter dictum.

\footnotetext{
${ }^{5}$ W.T.Murphy, The Oldest Social Science? The Epistemic Properties of the Common Law Tradition, Modern Law Review, 1991, p. 198
} 
Ratio decidendi is the Latin expression used to express the concept of reason behind a decision, this component of cases being more important of the two because it is the part of the case.

The second part is obiter dictum meaning an adjacent statement.

This element consists of minor details of the case such as the quotes of some judges, cases brought before the court to prove the precedent, comments of a social nature brought by the court, and any other elements that might be convincing before the court.

These elements are not clearly differentiated because of their interdependence.

In some exceptional cases, the doctrine of the preceding can be avoided by two methods, the first is called distinction and the second is called dissolution.

Even though names seem to explain themselves, they need to be explained in more detail:

Dissolution is the procedure by which the Parliament or the Supreme Court cancels the effects of a precedent, this decision having an effect on the cases currently being judged, those which will be judged in the future, and the most important aspect is that it has retroactive effect.

Because of this, it is a rare method. The logic behind the retroactivity of this procedure lies in the judge's role. When we analyze the traditional doctrine of British jurisprudence, it considers the judge not as a law creator, but as a discoverer of the law.

The moment when a court decided the outcome of a case and it became a law was not considered a new law, but a law discovered.

This conception is based on the naturalist theory that the law originates in divine commands or in collective morality, so judges discover laws that have already existed.

John Finnis, a basic theorist of this theory, proposes a form of naturalistic theory that can exist in the absence of religion, considering that the role of the law is to protect the individual values that make life beautiful (life, religion, knowledge, etc.) ensuring a harmonious social life.

Currently, the retroactive nature of the dissolution begins to disappear due to the popularization of the concept of legal positivism from the mid-twentieth century.

Legal positivism is a theory that proposes the separation of morality from the law, considering the law as a social construction in order to preserve the order of society that can coincide with moral values but does not depend on them.

One of the great thinkers of this trend is H.L.A Hart, professor of jurisprudence at Oxford University who is considered the father of legal positivism.

Distinction is the most common procedure that avoids the observance of the previous doctrine of careful analysis of cases in order to find meaningful differences.

This can be a very useful method for lawyers, who usually suggest to judges cases that might serve as law.

Even if it is just a professional use, the doctrine of the precedent is followed with holiness by the British courts.

\section{THE BASIC ELEMENTS OF THE TESTAMENT IN THE ENGLISH LEGISLATION}

As in the Romanian law, in the English law, the will is the will of the deceased. That is why there is "will", which refers to desire and "testament," which is the expression of desire in a form that produces legal effects, hence the concept of testamentary form.

In English law, we meet the definition of will and codicil. 
„ The testament is the declaration of a person's wishes about the "possessions" that he wants to pass on” ${ }^{\text {. }}$

The codicil is similar to the testament with regard to the purpose and legal formalities, but generally it is additional to the testament and is considered as an annex to the testament previously made, being drafted in order to add, vary or revoke testamentary provisions.

However, a codicil may exist independently of a will, that is, the revocation of a will, or part of a will, does not necessarily have the effect of revoking a codicil.

The word "testament", which is usually used to describe one of the instruments that express the will-intentions at a global level, is the formal expression referring to the desires of a deceased person.

After the testator's death, although in essence separate acts, the testament and the codicil are interpreted together as a single testamentary provision, because their legal effects are interdependent. If one of them is not valid, the other will produce legal effects.

\section{The Essential Characteristics Of A Testament}

In the English legislation, the will is designed to divide the deceased's patrimony among the heirs.

It may also be drawn up to designate bailiffs or other persons to manage or assist in the management of any part of the patrimony (for example, if the defunct leaves shares on the stock exchange/market where a person with specific knowledge is needed for divest or administer the patrimony), the appointment of guardians for minor children, the exercise of any rights relating to the patrimony, the revocation or amendment of any legal act or any other action that may produce legal effects after the death of the testator.

The essential characteristic of any testament is that it is basically a simple statement of the testator's intentions and can be "freely" revoked or modified.

By the time of death, the testator may change the will at any time, so it is "modifiable" and "no fixed effect", and "capable of producing legal effects on properties obtained after the testament" taxed $^{8}$.

Article 719 of the Income Tax Act 2007 indicates that a "testamentary gift" can be

The Income Tax Act states that any transaction or action that is associated with a transfer does not matter the nature of the operation or action may be taxed by the State, so any donation, testamentary gift, inheritance, etc. will be taxed as transactions associated with the transfer of goods.

\footnotetext{
${ }^{6}$ Halsbury`s laws of Englad, Wills and Intestacy, vol. 102, paragraf 1, Butterworths Publishing House, London, 2008.

${ }^{7}$ Halsbury`s laws of Englad, Wills and Intestacy, vol. 102, paragraf 2, Butterworths Publishing House, London, 2008.

${ }^{8}$ Income Tax Act 2007 art.719:

(1) Any associated operation is defined as any legal action in relation to:

(a) Any good transferred;

(b) Any good associated with another transferred asset;

(c) Any income derived from transferred assets;

(d) Any revenue generated by the goods that has been accumulated prior to the transfer (and belongs to the transfer beneficiary);

(2) It does not matter when the operation was carried out in relation to the transfer.
} 
Under the Law on Inheritance Fees of 1984, in some cases the testament may be subject to additional charges, and some legal transactions, such as rent in favor of one of the heirs, may be interpreted in such a way that they are taxed by other laws.

The English law distinguishes the testament from certain inter-vivos acts, such as:

- $\quad$ a donation mortis causa (that is, a donation made by a person on the deathbed) the realization of which is conditioned by the death of the author. If it does not die, the donation will no longer produce legal effects;

- $\quad$ a voluntary agreement with revocation power (for example, a contract in which the parties stipulate the possibility of canceling the act);

- $\quad$ a contract that will produce full legal effects only when the signatories perform their obligations;

- $\quad$ contracts that depend on future events;

- $\quad$ nomination of a beneficiary Testament;

- $\quad$ the rules of a pension scheme (i.e. pensions, food pensions and other regular payments that are made using the inheritance money).

The conclusion is that a testamentary will cannot be expressed in the form of an inter vivo contract.

\section{Testament in the form of deed}

The mere fact that a document contains the elements of a will does not mean that it is a will.

„Specifically, when deciding the nature of acts that were signed during the testator's life, it will be analyzed whether it was intended, or even the intention of the testament itself”" .

In the English law, if a person sells a property over which another person has real rights, those real rights become rights of possession of an amount equivalent to that real right. If this "currency exchange" has conditions or clauses that are linked to the death of one of the signatories, then this legal relationship is testamentary.

\section{Legal issues that a testament can clarify.}

„In the will, the deceased can foresee not only the way in which the patrimony will be divided among the inheritors but how it wishes other legal issues to be resolved after his death" ${ }^{10}$.

In principle, the testator must designate the names of the executors, and if there are children to designate the names of the legal guardians.

As far as debts are concerned, the deceased may choose to be paid as provided for by the law or to choose to be paid in a different form by a testamentary clause.

It may also change the way inheritance taxes will be paid, even if the English law indicates that all costs will be covered using the patrimony to be inherited.

„In the content of the will, there must be solutions to the emergence of perpetuity”"11. In the English law perpetuity is a situation in which a person is guaranteed a real asset on a property for more than 20 years, such as a rent or a license to live in a place.

\footnotetext{
${ }^{9}$ Halsbury`s laws of Englad, Wills and Intestacy, vol. 102, paragraf 3,. Butterworths Publishing House, London, 2008.

${ }^{10}$ Halsbury`s laws of Englad, Wills and Intestacy, vol. 102, paragraf 4, Butterworths Publishing House, London, 2008.

${ }^{11}$ Idem
} 
If the defunct did not explicitly state what the surviving spouse, the ex-spouse, the civil partner at the time of death, the former civilian partner, the children, the financial dependents, and the possible collocutors of his house, will inherited, these categories of people will have the right to request in court the modification of the testament in such a way that they can obtain what they should lawfully have had.

The person who deals with the legal aspect of the making of the will has the obligation to ensure that all the clauses are known and understood by the testator.

Also, if the person who writes the testament is the beneficiary of the testament, he must assure that he will not be influenced when writing it.

If the deceased was suffering from a mental illness, the people concerned have to prove that the person was mentally capable of writing a will.

Sometimes the testament is photographed, and this is a safety issue.

If the original testament is destroyed, a court will accept a photograph of that document if it is sufficiently clear and there is evidence that it is still valid.

\section{The Form of the Testament}

Preparing a testament professionally has unquestionable advantages.

However, the English law also accepts the form of a handwritten testament or any legal act expressing wills of will, provided that they respect the manner in which the legal inheritance is made.

It is also clear from these documents that the deceased intended to create will- rights.

" If such an act does not fulfill the formalities of the preparation of a will, it can be accepted by a court as a preliminary form of the will”, 12 .

An act that shows only the intentions or early desires of the deceased will not be considered as an act of testamentary value, because, as we have shown above, for an act to be of testamentary value must contain clearly represented intentions, and only then he will be accepted as a testament.

\section{Partially testamentary legal acts}

In the English law, a legal act can have both testamentary and inter-vivos effects between the deceased (when living) and the other party.

„A will can have clauses that produce inter-vivos effects” ${ }^{\text {"13. }}$.

\section{Conditional clauses that may have testamentary effects}

A clause or legal act may have a conditional testamentary effect.

The deceased may impose certain conditions relating either to the moment of opening the will or to the conditions in which it dies.

If the conditions are closely related to the possibility of death (hospitalization, travel, etc.), these will not be considered as conditional, but will be considered as the basis for the testament.

This explanation of the nature of the conditions is important because if a condition is impossible to fulfill, there is the possibility that the patrimony may become the property of the English state. This process is called "bona vacantia".

\footnotetext{
${ }^{12}$ Halsbury`s laws of Englad, Wills and Intestacy, vol. 102, paragraf 5,. Butterworths Publishing House, London, 2008.

${ }^{13}$ idem
} 
Also, if at the time of writing, the deceased is in a certain danger, it will be considered a reason for the making of the will.

In examining clauses and acts of will-nature, the court will accept evidence against or in favor of acts. Due to the fact that almost any contract drawn up by the deceased during his or her life may have testamentary clauses, an analysis procedure is needed by which interested parties can challenge or may propose acts in their favor.

If one of the people mentioned in the will is not clear enough, the court may also receive evidence in the form of testimonies from interested parties or the executor of the will.

\section{Common testament and mutual testament}

The common will is a will through which two people express their desire to divide individual property or co-ownership after their death. The English law does not accept this testament as one, but only a legal act that represents the wishes of the people who have made it, the properties being treated separately in an individual way. This type of testament is rarely used.

\section{Mutual testament is a kind of common testament.}

This form of will is distinct due to the fact that there are clauses whereby the signatories leave each other rights belonging to the personal patrimony. For example, $\mathrm{X}$ leaves $\mathrm{Y}$ a sum of money if he dies first or if $\mathrm{Y}$ leaves $\mathrm{X}$ a sum of money if he dies first.

„If there are separate wills with similar clauses, the wills will be analyzed together as a common testament" ${ }^{14}$.

The Doctrine of the Mutual Testament is criticized as lacking in clear principles and rules, which is why the courts have some ambiguity and lack of consistency when they have to make decisions in cases where an interested person is contesting this type of testament.

One of the certitudes of the mutual testament lies in the characteristics of the formation of this type of testament, namely: the first Signatory must write a testament in which to specify what is the share of the second Signatory or other legal act that it will not amend this testament without informing the Signatory 2. Signatory 2 goes through the same process.

\section{Delegating the power to write a will}

Even if a person can seek assistance from another person in order to write his will, he cannot fully delegate the will to another person.

If a person signing a testamentary document whose content he does not know or has clauses, sentences or even words that the Signatory is unaware of, that document will either not be accepted as a valid testament or will be considered a valid testament and will produce effects without those clauses being used.

In the testament, the deceased can appoint a person who has the power to determine the patrimony.

In current English legislation the creation of such a contract is accepted as a trust, the only real need is that the will must be clear enough in this regard. So the testamentary

\footnotetext{
${ }^{14}$ Halsbury`s laws of Englad, Wills and Intestacy, vol. 102, paragraf 8, Butterworths Publishing House, London, 2008.
} 


\section{Laura-Dumitrana Rath Boșca, Bogdan Bodea}

executor to receive such power lies in the clarity of the testamentary clause that specifies this method of sharing the patrimony.

If the deceased wants a part of the patrimony (clothes, real estate, money, etc.) to be passed on to a charity chosen by him or by the executor, this will be accepted without any additional conditions.

The court will not consider whether the executor has decided which charity will receive a donation specified in the will, but will be convinced that the gift is clearly defined, because if it is not clearly defined, that gift is not valid.

Due to the existing relationship between the deceased and the executor, the latter cannot have the right to inherit, because by trust, the person who has the will and the role of executor cannot have the right to inherit, one of the obligations of the relationship is to remain impartial of those who will be the beneficiaries of the will. He can not create or be the beneficiary of the will.

\section{Validity of a testament with extraneous elements}

A will is considered valid by statute and by common law.

There are elements related to cases that may be binding on certain wills, such as trust or postmortem donations, even if the will is made in a state other than England, or even if it is written in England and the patrimony is in another country. These concepts apply to both real estate and property on movable property.

There are people who leave a will but choose to apply the law to a state other than the English one. These may be people with dual citizenship or people who own property in the territories of other states and choose the laws of those countries either for practical reasons or for economic reasons.

If the desired legislation of the deceased is not specified, English legislation will be applied.

Typically, British successions do not accept wills that share a wholly foreign heritage.

The European Union allows a person to specify by will the country where the inheritance will be opened, as long as that person has the nationality of that country.

We mention the existence of a European Certificate of Succession, which is a form that allows proofing of the quality and rights of both the heirs and legatees and of the wills executors or administrators of the succession, in the succession opened from August 17, 2015.

\section{CONCLUSION}

Between the structure of the English law - common law - and that of continental law, there are considerable differences.

The doctrine of the preceding is a professional use that began in the nineteenth century and became one of the most important sources of law in the English legal system. It dictates the use of some of the legal reports that are drafted by various sources (private or public) as common law in similar cases.

In principle, this procedure seems very simple, but it is a big problem in the democratic legislative system where all the laws are voted by the Parliament.

The fact that some people can impose laws without them being elected by the population may sound worrying, but surprisingly, this practice has helped develop a system that is currently effective and relatively quick. 


\section{BIBLIOGRAPHY:}

1. Publius Iuventius Celsius, Digesta 111, Digesta - legal works;

2. M. Djuvara, Teoria generală a dreptului. Enciclopedia Juridică: Drept Raţional. Izvoare şi Drept Pozitiv, Bucharest: ALL, 1995;

3. Zlătescu V.D., Drept privat comparat, Bucharest, Oscar Print Publishing House, 1997;

4. $\quad$ Pierre Legrand, Dreptul comparat, Bucharest, Lumina Lex Publishing House, 2001;

5. W.T.Murphy, The Oldest Social Science? The Epistemic Properties of the Common Law Tradition, Modern Law Review, 1991;

6. Halsbury`s laws of England, Wills and Intestacy, vol. 102, Butterworths Publishing House, London, 2008;

7. Denise Meyerson, Understanding jurisprudence, Routledge Publishing House, 2007;

8. Gary Slapper and David Kelly, The English Legal System, Routledge Publishing House, 2016;

9. Sharon Hanson, Learning Legal Skills and Reasoning, Routledge Publishing House, 2016. 